\title{
Women Barriers and Empowerment Opportunities in The Nigerian Context
}

\author{
Thomas Achoda Omang ${ }^{1}$, John Thompson Okpa ${ }^{1 *}$, Ofem Nnana Okoi ${ }^{2}$ and \\ Joshua Iniama ${ }^{2}$ \\ ${ }^{1}$ Department of Sociology, Faculty of Social Sciences, University of Calabar, 10518, Calabar Nigeria \\ ${ }^{2}$ Department of Social Work, Faculty of Social Sciences, University of Calabar, 10518, Calabar, Nigeria
}

\begin{abstract}
This study examines women barriers and empowerment opportunities in Yakurr Local Government Area of Cross River State, Nigeria. The study design was exploratory using quantitative and qualitative data. Data is obtained from 660 women from Yakurr Local Government Area of Cross River State. The research used a multi-stage sampling technique. Data was analyzed using descriptive statistics such as percentages and frequency tables, while the Chi-square was used to test the significance of relationship between the two hypotheses stated. The findings of the study revealed that $58.3 \%$ of the respondents' report that they were aware of the availability of women empowerment programmes in their community. While, $31.9 \%$ of the respondents reported the provision of agricultural facilities as the widely available empowerment programme for women, 38.4\% indicated that non-governmental organizations were the major benefactors of women empowerment programmes. The findings of the study further showed that $39.5 \%$ of the respondents acknowledged that they had benefitted

ARTICLE INFO

Article history:

Received: 30 June 2020

Accepted: 17 September 2020

Published: 25 December 2020

DOI: https://doi.org/10.47836/pjssh.28.4.37

E-mail addresses:

omangta@unical.edu.ng (Thomas Achoda Omang)

okpajt@unical.edu.ng (John Thompson Okpa)

from women empowerment programmes. Equality for all can be achieved when women are allowed to make their own decisions on issues that concern them and act on those opportunities without fear.

Keywords: Education, empowerment opportunities, patriarchy system, women barriers, women empowerment
\end{abstract}

nnanaofem@unical.edu.ng (Ofem Nnana Okoi)

iniamajoshua@unical.edu.ng (Joshua Iniama)

*Corresponding author

ISSN: 0128-7702

e-ISSN: 2231-8534 


\section{INTRODUCTION}

Women have over time been relegated to the background in many societies of the world. All over the world, women have suffered various degrees of abuses, discriminations, marginalization and deliberate denial of their rights, but the dimension differs from society to society (Fiderikumo et al., 2017; Okeke, 2018). Even in the $21^{\text {st }}$ century, women suffer battery, they are falsely accused of practicing witchcraftcy, they are lynched for indulging in sexual activities and they are also raped and tortured while the perpetrators of these crimes move about freely in the society (Uyang et al., 2016). Women are usually given minor roles to play, they are treated as second class citizens and are mostly paired as servants to the men (Fiderikumo et al., 2017). Women have thus, been deprived socially, culturally, economically, politically and psychologically (Cornwall \& Edwards, 2010; Onyebuchi \& Rafiu, 2020). Syed (2018) observed that in southcentral Asia, women suffered cultural, racial, regional, economic, political and religious deprivations, stigmatizations and abuses. In Pakistan particularly, women are less educated compared to men, they are prone to sickness and they occupy the lowest social, political and economic status in the society (Raphel, 2014; Syed, 2018). In African culture, women remain silent while the men talk and take all the decisions that would be binding on women (Bako \& Syed, 2017). In Ghana, women are denied access to land, and they are also not entitled to credit facilities, they are not permitted to register as members of farmers' organisations, the same women are not allowed to access agricultural extension services and training (Atuase, 2018; International Centre for Research on Women, 2013). That is even on a lighter note. In most communities in Africa and Nigeria in particular, women are not allowed to attend extended family meetings, let alone to contribute to family matters. The domineering actions of men have conditioned women in traditional African societies into accepting their deprivations as their fate which cannot be altered (Bayeh, 2017; Oke, 2015).

In Nigeria, women are faced with a great challenge, as they constitute the poor and illiterate majority (Ayevbuomwan et al., 2016). Their productive roles are considered as a share of their domestic responsibilities (Eze et al., 2016). The men are still responsible for the key management decision making even though the women constitute about 60 to 80 per cent of the agricultural labour force in Nigeria, and they produce about two-thirds of the food crops for the family (Alese, 2013; Obayelu, \& Chime, 2020). These women who occupy a critical place in our economic development are in most cases ignored, underestimated, relegated to the background and rendered voiceless when production and management decisions are made even within the household (Ilavbarhe \& Izekor, 2015). There is no empirical evidence to show that in human history men have been subjected to such dehumanizing and agonizing treatment like the women. Unfortunately, most women now resign themselves to the culture of 
silence as a result of ignorance of what constitutes their rights in the family and the society at large (Amaechi, 2019; Duke, 2010). Literature in developing economics further highlights how class and gender has long been regarded as an important indicator in determining the patterns of oppression experienced by the women. For example, Armstrong's (2020) research on "Marxist and socialist feminism" reveals how class relations of capitalism enforced the gender hierarchies that anchored women's oppression. Elizabeth (2015) and Fasina's (2017) works on gender suggest a similar pattern whereby gender status becomes an important predictor of women oppression and travails. Though studies such as these underscore the important effects of class, gender status and women deprivation and oppression, the question that readily comes to mind is whether these relations remain constant for all women.

However, different factors have been identified as adversely affecting the process of women's all-around empowerment. These factors include the psychological make-up of women, their reproductive responsibilities, their total personality and external environment-categorized into the social, economic, educational, political and psychological and cultural values by which societies make the differentiation between men and women (Bako \& Syed, 2017; Mandal, 2013). These impediments are sustained by the male-dominated social structure, high rate of poverty among women, and gender division of labour (Bako \& Syed, 2017; Onyishi, 2011).
Equality for all can be achieved if women are no longer treated as domestic workers, if they are liberated from all forms of generational discrimination, if the women are allowed political inequality with men, if the women are allowed full control over material resources accruable to them, if they are also given full protection against subtle male violence, male intimidation and male control (Bayeh, 2017; Onyishi, 2011). Put differently, empowerment, according to Amaechi (2019) and Fiderikumo et al. (2017), requires the transformation of the structures of subordination through changes in the law, changes in property rights and changes in other institutions that reinforce and perpetuate male domination. This could be done by improving the educational, political and economic status of women to enable them to participate actively in the socio-economic development of the society. The role of women empowerment programmes in achieving equality for women and liberating them from all forms of institutionalized discriminations, and pull them out of economic servitude, is still a subject of debate among scholars. Thus, this study empirically examined existing women empowerment opportunities and determine their strength in facilitating the achievement of equality for all women in Yakurr Local Government Area of Cross River State, Nigeria.

\section{Explaining the Link}

Participatory Approach. The participatory model propounded by Fiorino and Bowels (2001) advocates for a support system 
which ensures that the women themselves get involved in the planning, execution and implementation of women empowerment programmes which will enhance and impact their lives for an all-round empowerment and development. The participation of women in the structural process of the women empowerment programmes is generally supported due to its potential for providing cost-effective and beneficial measures for the government. This approach is in agreement with the views of Fiderikumo et al. (2017), who opined that women empowerment programmes would increase the acceptance of such programmes and strengthen the confidence of the women in government decisions, with regards to empowerment programmes and the impact it would make in the lives of the women. The contention is that, the empowerment of women in Nigeria should be a function of the women themselves this will enable them to take their destinies in their hands in order to improve their socio-economic conditions (Onyebuchi \& Rafiu, 2020).

However, socio-economic dynamics such as power differences and gender social relations have been identified as factors affecting women's participation in project planning and implementation. In addition to that, ineffective communication networks and inadequate capacity building among leaders are also identified as barriers to good flow of information and planning (Oke, 2015). The aim of women empowerment is to enhance the socio-economic status of women through creating an economic culture that will address the technical know-how in the pursuit of women's multifaceted roles, retooling them with various economic ventures as well as enhancing the emancipation of women from poverty. This is because women are "generally poor" and constitute majority of the population thus, targeting them will be a fundamental prerequisite for any poverty reduction strategy to be effective (Akpan, 2015; Danjuma et al., 2013).

\section{METHODS}

\section{Study Setting and Population}

The study was conducted in Yakurr Local Government Area (LGA) of Cross River State, Nigeria. It is one of the 18 local government areas that make up Cross River State. Yakurr LGA was created out of Obubra Local Government in 1987. Yakurr LGA headquarters is in Ugep. The area lies between latitude $5^{\circ} 40^{\prime}$ and $6^{\circ}$ $10^{\prime} \mathrm{N}$ and longitude $8^{\circ} 2^{\prime}$ and $6^{\circ} 1^{\prime} \mathrm{E}$ and $120 \mathrm{~km}$ North of Calabar. Geographically, Yakurr shares boundaries to the West with Obubra LGA, to the East with Biase LGA, to the North with Abi LGA and to the South with Akamkpa LGA (Ugal, 2015). The major language spoken by the people is "Lokạa". The area comprises 13 wards and is inhabited by the people of Agoi, Ibami, Assiga, Mkpani, Ekon, Nko, Ugep and Idomi. The dominant language is Yakurr. The people of Yakurr LGA celebrate their new yam festival and the most pronounced festival in Yakurr is "Leboku" (Ibok et al., 2015). The choice of Yakurr LGA is because of the perceived high rate of patriarchal tendencies and low quality of life among 
the women, especially, in the rural area. The target population to be studied was 158,674 women. The target population of the study was made up of women from 18 years and above residing in Yakurr L.G.A, comprising the married and the unmarried, the educated and the uneducated, the employed and the unemployed.

\section{Design and Sampling}

Quantitative data was obtained from 622 respondents, using a multi-stage sampling technique which in this study entailed the selection of community clusters, streets, villages, housing units and respondents through simple random and purposive sampling technique. Qualitative data were collected from six participants, purposively selected in houses for In-depth Interview (IDI), and thirty-two (32) participants were selected purposively for Focus Group Discussion (FGD). Six (6) participants were purposively selected for the In-depth Interview (IDI). This brought the total number of respondents to 660. For the indepth interview (IDI) three women leaders and three chairpersons of cooperatives were selected. These categories of people were selected due to the vital position they occupy in the area and also their experiences. For the Focus Group Discussion (FGD), four FGD sessions were conducted with adult women who were 18 years and above; the FGD was made up of four groups. Sixteen (16) female participants were selected purposively from both wards in the urban area and 16 female participants were also selected purposively from Idomi and Mkpani, which are rural areas. The combined approach is drawn from the potential strengths of both qualitative and quantitative data and it facilitates different avenues of exploration which enrich the evidence and enable research questions to be answered more deeply.

\section{Ethical Consideration and Data Collection Procedure}

The research complied with all known ethical principles guiding Social Science research. These include disclosure policy, informed consent, safety protocols, anonymity and confidentiality. Before the main instrument was administered, $10 \%$ of the sample size was used to conduct a pre-test in different locations not selected for the study. The instrument was also subjected to content and face validity. The researcher administered the questionnaires with the help of four research assistants who were fluent in English and Yakurr dialects. The test-retest reliability was adopted to determine if the responses were reliable. For the IDI and FGD, a researcher conducted the interview and discussion sessions using a recorder with the permission of the participants, while, one of the research assistants operated the recorder and took down notes as well. The respondents were duly notified and appointment scheduled before the interview. This was to avoid meeting them unprepared and to create a conducive environment that enhanced their full participation and also to guarantee the quality of information to be generated during the session. 


\section{Data Analysis}

This study employed both quantitative and qualitative methods of data analysis. The quantitative data from the questionnaire were coded, computer-processed and analyzed using version 20 of the Statistical Package for Social Sciences (SPSS). Descriptive statistics such as percentages and frequency tables were used in presenting the results. The qualitative data were transcribed first in the local language and translated into English but the local language versions carry the same meanings with the English language version. In going through the transcription, phrases with special meanings were identified. They served as illustrative quotes to complement the statistical data.

\section{RESULTS}

A total of six hundred and twenty-two (622) copies of the questionnaire was distributed in the selected communities of the study area (Yakurr LGA) and 612 copies of the survey instrument were validly completed and retrieved which put the response rate at
$98.4 \%$ response rate, while, $1.6 \%$ (10) were unusable because they were uncompleted and some were not returned. Table 1 shows that $50.2 \%$ of the respondents are from Ugep community. Other communities sampled were Mkpani (12.6\%), Asiga (12.6\%), Idomi (12.4\%) and Ekori (12.3\%). Fiftytwo $(52.0) \%$ of the respondents were 45 years and above, $19.9 \%$ were within the age bracket of $36-44$ years. This was followed by those aged $27-35$ years (17.8\%), while, those aged $18-26$ years were the least $(10.3 \%)$. This implies that majority of the respondents sampled were mature-(45 years and above). The marital status distribution showed that respondents who were married were noticeably more than those in any other category and they made up $55.7 \%$ of the sample, this was followed by singles $(20.4 \%)$ and widowed women (18.0\%). Divorced women were $3.3 \%$ and those who were separated $(2.6 \%)$ were the least sampled. Data regarding the educational qualification of respondents revealed that $33.8 \%$ of the respondents had

Table 1

Socio-demographic data of respondents $(N=612)$

\begin{tabular}{lllll}
\hline S/N & Variables & Options & Response rate & Percentage \\
\hline 1. & Community & Ugep & 307 & 50.2 \\
& Mkpani & 77 & 12.6 \\
& Asiga & 77 & 12.6 \\
& Idomi & 76 & 12.4 \\
& Ekori & 75 & 12.3 \\
& Total & $\mathbf{6 1 2}$ & $\mathbf{1 0 0}$ \\
\hline
\end{tabular}


Table 1 (Continued)

\begin{tabular}{|c|c|c|c|c|}
\hline $\mathrm{S} / \mathrm{N}$ & Variables & Options & Response rate & Percentage \\
\hline \multirow[t]{5}{*}{2.} & Age & $18-26$ years & 63 & 10.3 \\
\hline & & $27-35$ years & 109 & 17.8 \\
\hline & & $36-44$ years & 122 & 19.0 \\
\hline & & 45 years and above & 318 & 52.0 \\
\hline & & Total & 612 & 100 \\
\hline \multirow[t]{6}{*}{3.} & Marital status & Single & 125 & 20.4 \\
\hline & & Married & 341 & 55.7 \\
\hline & & Divorced & 16 & 3.3 \\
\hline & & Separated & 20 & 2.6 \\
\hline & & Widowed & 110 & 18.0 \\
\hline & & Total & 612 & 100 \\
\hline \multirow[t]{5}{*}{4.} & $\begin{array}{l}\text { Educational } \\
\text { qualification }\end{array}$ & $\begin{array}{l}\text { No formal } \\
\text { education }\end{array}$ & 84 & 13.7 \\
\hline & & Primary education & 155 & 25.3 \\
\hline & & $\begin{array}{l}\text { Secondary } \\
\text { education }\end{array}$ & 166 & 27.1 \\
\hline & & Tertiary education & 207 & 38.8 \\
\hline & & Total & 612 & 100 \\
\hline \multirow[t]{3}{*}{5.} & Residential area & Rural & 305 & 49.8 \\
\hline & & Urban & 307 & 50.2 \\
\hline & & Total & 612 & 100 \\
\hline
\end{tabular}

Source: Fieldwork (2020)

completed their tertiary education, $27.1 \%$ had obtained their secondary education certificate. Also, 25.3\% were done with their primary education, while, $13.7 \%$ had no formal education. Urban dwellers made up $50.2 \%$ of the respondents, while, $49.8 \%$ were rural dwellers.

\section{Knowledge of Women Empowerment Programmes}

The results in Table 2 shows that a greater percentage of the respondents $(58.3 \%)$ reported that they were aware of the availability women empowerment programmes in their community, 6.9\% revealed that they were not aware of any 
available women empowerment programme in their community, while, $34.8 \%$ indicated that they did not know if there was any available women empowerment programme in their community.

A trader at Ugep market during the IDI interview had this to say about her awareness of any available women empowerment programmes in her community:

Yes, there are various types of empowerment programmes in my community, but what is available is not adequate for everybody. Only a few people from the community have benefitted from some of the existing empowerment programmes in the community. (IDI/Trader/Ugep community).

One of the beneficiaries of women empowerment programmes in an IDI interview reported that:

I am aware that from time to time philanthropists, religious organisations, even politicians come to my community to specifically empower women, mostly, those who are helpless and vulnerable. In my church women are taught how to make soap, detergents, pastries and other things which they can start up with small capital. (IDI/woman leader/ Mpkani community).

An excerpt from an informant in an FGD session who shared a contrary opinion about the knowledge of existing women empowerment programmes in her community:

I cannot categorically confirm to you whether empowerment programmes exist for women or not. But I have not seen anybody from this community that has benefitted from any empowerment programmes, be it woman or man. During the 2019 elections, some group of politicians from my community attempted empowering women but could not continue with the programme for reasons best known to them.

Table 2

Percentage distribution of respondents on the awareness of any available women empowerment programme in their community

\begin{tabular}{lll}
\hline Available programme & Frequency & Percentage (\%) \\
\hline Yes & 357 & 58.3 \\
No & 42 & 6.9 \\
Do not know & 213 & 34.8 \\
Total & 612 & 100.0 \\
\hline
\end{tabular}

Source: Fieldwork (2020) 
Existing Empowerment Programmes in Yakurr

Data in Table 3 reveals that the most commonly mentioned empowerment programmes was the provision of agricultural products $(31.9 \%)$, followed by skill acquisition/development (29.4\%). Another $25.3 \%$ reported clearing of farm roads, $24.5 \%$ said establishing of small- scale businesses, while, $21.7 \%$ mentioned renovation of market stalls. A total of $14.5 \%$ respondents said the availability of adult literacy programmes, $12.9 \%$ mentioned of the availability of scholarship programmes for children of widows, $5.9 \%$ said there was the availability of micro-credit facilities, while, only $1.5 \%$ had other views.

Table 3

Percentage distribution of respondents by the type of women empowerment programme available in their community

\begin{tabular}{llll}
\hline Available programmes & Mentioned & Not mentioned & Total \\
\hline Micro-credit facilities & $36(5.9)$ & $576(94.1)$ & $612(100.0)$ \\
Renovation of market stalls & $133(21.7)$ & $479(78.3)$ & $612(100.0)$ \\
Clearing of farm roads & $155(25.3)$ & $457(74.7)$ & $612(100.0)$ \\
$\begin{array}{l}\text { Establishing of small-scale } \\
\text { businesses }\end{array}$ & $150(24.5)$ & $462(75.5)$ & $612(100.0)$ \\
$\begin{array}{l}\text { Scholarships for children of } \\
\text { widows }\end{array}$ & $79(12.9)$ & $533(87.1)$ & $612(100.0)$ \\
Provision of agricultural products & $195(31.9)$ & $417(68.1)$ & $612(100.0)$ \\
Skill acquisition/development & $180(29.4)$ & $432(70.6)$ & $612(100.0)$ \\
Adult literacy & $89(14.5)$ & $523(85.5)$ & $612(100.0)$ \\
Others & $9(1.5)$ & $603(98.5)$ & $612(100.0)$ \\
\hline
\end{tabular}

Source: Fieldwork (2020)

An indication of the availability of women empowerment programmes as reported in the study is evident from the response of a woman leader:

I have heard of many women empowerment programmes such as microcredit facilities (loan). It is an empowerment programme by Ugep community bank designed to help women access loan to carry out their small scale businesses. Also, Livinus Ofem foundation is a religious organization 
saddled with the responsibilities of empowering women, especially, widows by giving scholarships to their children. (IDI/Female/30/Urban/ Chairlady of Cooperative society).

An excerpt from the view of a participant of the availability of women empowerment programmes is transcribed below:

Women in my community have had access to different empowerment programmes, which has boosted their productivity, increased economic diversification and income equality. Agricultural products like fertilizers, farm seedlings etc., have been provided to women farmers, especially, the vulnerable among them. Training has also been organised for widows on how to increase their yields, how to apply the fertilizers and other chemicals given to them. Money has also been distributed to widows to enable them to hire labour and get other things, which they may need during planting season. (FGD with a 43-year-old Civil servant in Mkpani community).

\section{Benefactors of Women Empowerment Programmes}

In Table 4 the greater percentage of respondents $(38.4 \%)$ indicate that nongovernmental organizations have provided the empowerment programmes, $14.2 \%$ mentioned Government, $3.3 \%$ said philanthropists, while, $2.5 \%$ state others Faith-Based Organizations (FBO).

Data from FGD conducted in Mpkani buttresses this point. According to them, NGO's are the major providers of empowerment programmes in this community. A 45-year-old housewife

Table 4

Percentage distribution of respondents by the group that provides women empowerment programmes/projects in their community

\begin{tabular}{lll}
\hline Benefactors & Frequency & Percentage (\%) \\
\hline $\begin{array}{l}\text { Government } \\
\text { Non-governmental }\end{array}$ & 87 & 14.2 \\
organization & 235 & 38.4 \\
Philanthropists & 20 & 3.3 \\
Faith-Based Organizations & 15 & 2.5 \\
Not applicable & 255 & 41.6 \\
Total & 612 & 100.0 \\
\hline
\end{tabular}

Source: Fieldwork (2020) 
narrated how they benefited from scholarship "well we thank God that the Livinus Ofem foundation, which is a religious group, found us worthy of granting a scholarship for us since it was meant for children of widows, they empowered my children and today they are in school." Additionally, an IDI conducted in Idomi revealed thus:

.....some time ago in this community, I was among those that were privilege to have received training from Richard Foundation a non-governmental organization. We were trained on hair making for about one year and six months. Thereafter, we were given a sum of one hundred thousand naira each to set up our saloon and by the grace of God I am living well and meeting up my demands. (IDI/cooperative society leader/ Idomi community).

\section{Access to Women Empowerment Programmes}

The result in Table 5 reveals that a significant percentage of the respondents (39.5\%) indicated that they had benefitted from women empowerment programmes. Unfortunately, only $58.3 \%$ said they had not benefitted from women empowerment programmes, while, a few $2.1 \%$ mentioned that they did not know if what they had benefited in the past was an empowerment programme or not.

Table 5

Percentage distribution of the respondents on whether they had benefited from women empowerment programmes

\begin{tabular}{lll}
\hline Benefited & Frequency & Percentage (\%) \\
\hline Yes & 242 & 39.5 \\
No & 357 & 58.3 \\
Don't know & 13 & 2.1 \\
Total & 612 & 100.0 \\
\hline
\end{tabular}

Source: Fieldwork (2020)

Congruently, the FGD with the women of Ijom ward revealed that there were a few empowerment programmes women could benefit from. She said:

As for me, the only women empowerment programme I have benefited from is that of the micro-credit facility sponsored by the Microfinance bank. As I am talking to you now I collected fifty thousand naira with less interest rate of one hundred naira per month. I used that money to open a restaurant where I sell 
food like garri and soup, rice, beans, etc. And I have been making a lot of profit out of the business. That money has helped me take care of my children, especially, as regards their feeding, education and health matters (FGD with a 41-year-old trader in Ijom ward).

Additionally, data from the FGD has a contrary view. Three participants indicated that they were yet to benefit from any women empowerment programme in their community. Below are excerpts of their responses:

These programmes when they come, are only shared among the women executives and their friends. We have not benefitted from any free skill acquisition or any other type of empowerment programme. We only hear about these things on the television but in reality, I have not seen or benefited from any of these programmes. The last time they asked us to pick up forms from the secretariat for skill acquisition programmes I did but no one called me. Even my application for a loan to help my business has not been attended to. (FGD session with younger women; 39-year-old trader in Idomi community).

\section{Factors Hindering Women Empowerment Programmes in Yakurr}

As can be deduced from the first row in Table 6, 97.2\% of the respondents agreed that education affected women participation in empowerment programmes, while, $2.8 \%$ disagreed. In the second row, $56.2 \%$ pointed out that women who were educated partake more in empowerment programmes, while $43.8 \%$ disagreed. This is also the case with data presented in the third row, in which, $50.3 \%$ of the respondents agreed that women reproductive responsibilities had acted as a strong impediment to women empowerment. However, this was not upheld by $49.7 \%$ of the respondents who disagrees to that view. In the fourth row, $62.1 \%$ of the respondents agreed that the patriarchal social structure that favoured the men more than women was also a factor working against the empowerment of women. On the contrary, $37.9 \%$ of the respondents disagreed, noting that such was not applicable in their community. In the fifth row, $72.4 \%$ of the respondents agreed that the location of the women affected their participation in empowerment programmes. On the contrary, $27.6 \%$ of the respondents disagreed. The sixth row equally showed that majority of the respondents $(85.7 \%)$ agreed that certain social norms, beliefs, customs and values in rural communities did not encourage women empowerment, while, $14.2 \%$ disagreed. In the seventh row, 93.1\% of the respondents agreed that a high level of poverty among women works against their all-round empowerment but on the contrary, $6.8 \%$ of the respondents disagreed with that position. The last row equally showed that majority of the respondents $94.1 \%$ agreed that lack of employment opportunities for women prevented their empowerment, while, $5.9 \%$ disagreed with 
them. A summation of all data presented in this section shows that majority of the respondents are of the view that certain socio-economic cum cultural factors are working against the empowerment of women in Yakurr Local Government Area of Cross River State, Nigeria.

Table 6

Percentage distribution of respondents on factors hindering women empowerment programmes

\begin{tabular}{llll}
\hline Statements & Agree & Disagree & Total \\
\hline $\begin{array}{l}\text { Level of education does affect participation } \\
\text { in women empowerment programmes }\end{array}$ & $595(97.2 \%)$ & $17(2.8 \%)$ & $612(100.0 \%)$ \\
$\begin{array}{l}\text { Women who are educated partake more in } \\
\text { empowerment programmes }\end{array}$ & $344(56.2 \%)$ & $268(43.8 \%)$ & $612(100.0 \%)$ \\
$\begin{array}{l}\text { Women reproductive responsibilities have } \\
\text { acted as a strong impediment to women }\end{array}$ & $308(50.3 \%)$ & $304(49.7 \%)$ & $612(100.0 \%)$ \\
empowerment & & & \\
$\begin{array}{l}\text { The patriarchy social structure that favours } \\
\text { the men more than women is a factor }\end{array}$ & $380(62.1 \%)$ & $232(37.9 \%)$ & $612(100.0 \%)$ \\
$\begin{array}{l}\text { working against the empowerment of } \\
\text { women }\end{array}$ & & & \\
$\begin{array}{l}\text { The location of the women affects their } \\
\text { participation in empowerment programmes }\end{array}$ & $443(72.4 \%)$ & $164(27.6 \%)$ & $612(100.0 \%)$ \\
$\begin{array}{l}\text { Certain social norms, beliefs, customs } \\
\text { and values in rural communities do not } \\
\text { encourage women empowerment }\end{array}$ & $525(85.7 \%)$ & $87(14.2 \%)$ & $612(100.0 \%)$ \\
$\begin{array}{l}\text { High level of poverty among women works } \\
\text { against their all-round empowerment }\end{array}$ & $570(93.1 \%)$ & $42(6.8 \%)$ & $612(100.0 \%)$ \\
$\begin{array}{l}\text { Lack of empowerment opportunities } \\
\text { prevent women from empowerment }\end{array}$ & $576(94.1 \%)$ & $36(5.9 \%)$ & $612(100.0 \%)$ \\
\hline
\end{tabular}

Source: Field survey (2020)

Test of Hypotheses

\section{Hypothesis One.}

Substantive hypothesis $\left(H_{1}\right)$ : Women with a higher level of education are more likely to feel the positive impact of women empowerment programmes than those with a lower level of education 
Null hypothesis $\left(H_{0}\right)$ : Women with a higher level of education are less likely to feel the positive impact of women empowerment programmes than those with a lower level of education

Table 7

Percentage distribution of respondents by the level of education and the impact of women empowerment programmes

\begin{tabular}{llll}
\hline \multirow{2}{*}{ Level of education } & \multicolumn{2}{c}{ Feelings/impact of women empowerment } & Total \\
& \multicolumn{2}{c}{ programmes } & \\
\cline { 2 - 3 } & Positive impact & Negative impact & \\
\hline Low education & $154(64.4 \%)$ & $85(35.6 \%)$ & $94(100.0 \%)$ \\
High education & $203(54.4 \%)$ & $170(45.6 \%)$ & $373(100.0 \%)$ \\
Total & $357(58.3 \%)$ & $255(41.7 \%)$ & $612(100.0 \%)$ \\
\hline
\end{tabular}

$\chi^{2}=6.007^{\mathrm{a}} \mathrm{df}=1, \mathrm{p}<0.014$ critical $/$ table value $=3.841$

Source: Fieldwork (2020)

The Chi-square test result in Table 7 with a lower level of education is, hereby, shows that computed $\chi^{2}$ is 6.007 , while, rejected.

the critical/table $\chi^{2}$ value is 3.841 and $\mathrm{df}=1$. The test showed that there was a statistically significant relationship ( $\mathrm{P}$ $<0.014$ ) between education and the impact of women empowerment programmes. From the decision rule, since the chi-squared calculated $\left(6.007^{\mathrm{a}}\right)$ is greater than the chisquared tabulated (3.841), we, thus, accept the substantive hypothesis which stated that women with a higher level of education were more likely to feel the positive impact of women empowerment programmes than those with a lower level of education, while, the null hypothesis which stated that women with a higher level of education were less likely to feel the positive impact of women empowerment programmes than those

\section{Hypothesis Two.}

Substantive hypothesis $\left(H_{l}\right)$ : Women in urban communities are more likely to feel the positive impact of women empowerment programmes than those in rural communities Null hypothesis $\left(H_{0}\right)$ : Women in urban communities are not more likely to feel the positive impact of women empowerment programmes than those in rural communities To gain clarity on the data presented in Table 8 , given the computed $\chi^{2}=$ $27.680^{\text {a }}$ and critical/table $\chi^{2}$ value of 3.841 ; df $=1$, the test showed that there was a statistically significant relationship $\left(\mathrm{p}_{<}=0.000\right)$ between the place of residence and the impact of 
Table 8

Place of residence and impact of women empowerment programmes

\begin{tabular}{llll}
\hline \multirow{2}{*}{ Place of residence } & \multicolumn{2}{c}{ Feelings/impact of women empowerment } & Total \\
& \multicolumn{2}{c}{ programmes } \\
\cline { 2 - 3 } & Positive impact & Negative impact & \\
\cline { 1 - 3 } Urban area & $147(47.9 \%)$ & $160(52.1 \%)$ & $307(100.0 \%)$ \\
Rural area & $210(68.9 \%)$ & $95(31.1 \%)$ & $305(100.0 \%)$ \\
\hline Total & $357(58.3 \%)$ & $255(41.7 \%)$ & $612(100.0 \%)$ \\
\hline
\end{tabular}

$\chi^{2}=27.680^{\mathrm{a}} \mathrm{df}=1, \mathrm{p} \angle 0.000 \mathrm{critical} /$ table value $=3.841$

Source: Fieldwork (2020)

women empowerment programmes. Therefore, we conclude that the substantive hypothesis which states that women in urban communities are more likely to feel the positive impact of women empowerment programmes than those in the rural communities is hereby accepted while the null hypothesis which states that women in urban communities are less likely to feel the positive impact of women empowerment programmes than those in the rural communities is hereby rejected.

\section{DISCUSSION}

The study showed that the majority (58.3\%) mentioned that they knew about the women empowerment programmes available in the study area. Amongst the available women empowerment programmes, the majority $(31.9 \%)$ mentioned the provision of agricultural inputs. On the issue of benefactors of the empowerment programmes majority (38.4\%) mentioned non-governmental organizations. Furthermore, the majority
$(58.3 \%)$ of the respondents' stated that they had not benefitted from the available empowerment programmes. Their reason for this is traceable to the uneven distribution of these programmes when they arrive in the community. Findings from this study further revealed that the majority (97.2\%) of the respondents strongly agreed that the level of education affected participation in women empowerment programmes.

The findings of Karabona (2015) indicates that adult education empowers women through the use of skills in various economic sectors, and for this case, adult education is relevant to women in generating income. It can be deduced from the study also that adult education does empower women and equip them with adequate skills that help generate income for them, which, if not in place will hinder their access to women empowerment programmes from making the intended impact in the lives of the women. A sizeable $56.2 \%$ said that women who were educated partook more 
in empowerment programmes. From the study of Hora (2014), it can be deduced that an improved educational status of women will aid their access to leadership and decision-making processes and access to empowerment programmes which is needed for their well-being. Of the respondents, $50.3 \%$ agreed that women reproductive responsibilities had acted as a strong impediment to women empowerment, while $62.1 \%$ of the respondents agreed that the patriarchal social structure that favoured the men more than women was a factor working against the empowerment of women.

According to Onah (2011) and Osita (2016), patriarchal societies ensure that the woman is under the control of some men in the image of her father, brother or husband. If a woman is not ruled as daughter or sister, she is of necessity, governed as a wife. Hence, marriages are still male-propelled in Nigeria. A total of $72.4 \%$ respondents agreed that the location of the women affected their participation in empowerment programmes, majority of the respondents $(85.7 \%)$ agreed that certain social norms, beliefs, customs and values in rural communities did not encourage women empowerment, 93.1\% of the respondents agreed that high level of poverty among women worked against their all-round empowerment, while, the majority of the respondents (94.1\%) agreed that lack of employment opportunities for women prevented their empowerment. This is supported by the findings of Uwantege and Mbabazi (2015), and Mbara et al. (2015) as they reported that lack of employment opportunities or participation in such opportunities encouraged abuse and prevented empowerment of the women. Their study concluded that employment opportunities would empower women and reduced the incidences of abuse and domestic violence.

The emphasis of the participatory model by Fiorino and Bowels (2001) is the active involvement of people (women) in the decisions that affect their lives; through initiating, planning, negotiating, and implementing programmes that have direct bearing to their development. The findings of the study reveal how women barriers can be eliminated by allowing women to take part in initiating, planning, executing and monitoring development programmes that directly affect their lives. The findings further show that women who have benefitted from empowerment programmes that boost their income and enhance their literacy level, easily overcome social barriers, and they attain self-fulfillment and gain the ability to achieve their highest personal aspirations and goals in life. This, by implication, means that involving the women for whom empowerment programmes are meant for in the planning, initiation and decision-making processes, will increase the overall impact of the women empowerment programmes.

More so, the test of Hypothesis One revealed that $54.4 \%$ of respondents with a high level of education indicated that empowerment programmes had positive impacts on them. This finding is in lieu with that of Sperling et al. (2016). From their finding, quality education was closely related to a woman's ability to access decent 
work subsequently and effectively utilized any empowerment programme made available. Also, in the test of Hypothesis Two, $68.9 \%$ of the rural dwellers indicated that they had positive feelings towards women empowerment programmes and the chi-square value $\left(\chi^{2}=27.680^{\mathrm{a}} \mathrm{df}=1, \mathrm{p}<\right.$ 0.000 ) showed that there was a statistically significant relationship between residence and positive impact of women empowerment programmes. Tabassum et al. (2019) reached some conclusions that corroborated with the above findings that the place of residence played a significant role in the women empowerment in Bangladesh. Similarly, Josephat et al. (2018) and Kazembe (2020), reported that the number of lived in years in the area (residence) and residence area positively influenced women empowerment.

\section{CONCLUSION}

\section{Recommendations}

The study examined women barriers and empowerment approaches in Nigeria, using Yakurr Local Government Area of Cross River State as a case study. Based on the empirical evidence emanating from both descriptive and inferential statistics employed in the analysis of the data, it has been observed that majority of the women $(58.3 \%)$ were aware of the existing women empowerment programmes Although, the study found that majority of the women were aware of the existing empowerment programmes, the frequency of those that had benefitted was however reported to be low by almost half of the respondents $(39.5 \%)$. However, women that had benefitted from various empowerment programmes in Yakurr Local Government Area of Cross River State, Nigeria had had access to microfinance, skill acquisition, and agricultural programmes. These had helped in reducing poverty, increasing household income, reducing child mortality, and increasing education delivery in the study area. However, several factors such as psychological make-up of the individual woman and the socio-cultural, economic, educational and political realities that made up the external environment had served as impediment to women's allaround empowerment. The study, therefore, concludes that in order to have more women's participation in politics, eliminate gender inequality, and strengthen women economic power more support services should be made available and accessible to women. It, therefore, becomes imperative to create more awareness on the issue of women empowerment and men should be encouraged to take an active part in this campaign. Equality for all can be achieved when women are allowed to make their own decisions around issues that concern them and act on those opportunities without fear.

\section{ACKNOWLEDGEMENT}

We appreciate the contributions of Prof. (Mrs.) Uzoma Odera Okoye at various stages of this work. 


\section{REFERENCES}

Akpan, G. E. (2015). Empowering women and youth in micro-and small-scale enterprises (MSSEs) for wealth creation. International Journal of Asian Social Science, 5(2), 52-63.

Alese, O. D. (2013). Women and poverty alleviation programmes in Nigeria: The NAPEP approach. Academic Journal of Interdisciplinary Studies, 2(3), 515-523. doi: 10.5901/ajis.2013.v2n3p515

Amaechi, L. N. (2019). Women empowerment and sustainable development in Nigeria. The International Journal of Social Sciences and Humanities Invention, 6(11), 5711-5712. doi: 10.18535/ijsshi/v6i11.04

Armstrong, E. (2020). Marxist and socialist feminism. In N. Naples (Ed.), Study of women and gender. Northampton, England: Faculty Publications.

Atuase, D. (2018). Gender equality and women empowerment in Ghana, the role of academic libraries. Journal of Applied Information Science, 6(2),14-2.

Ayevbuomwan, O. S., Popoola, O. A., \& Adeoti, A. I. (2016). Analysis of women empowerment in rural Nigeria: A multidimensional approach. Global Journal of Human-Social Science: Sociology and Culture, 16(6), 35-48.

Bako, M. J., \& Syed, J. (2017). Women's marginalization in Nigeria and the way forward. Journal Human Resource Development International, 21(5), 425-443. doi: 10.1080/13678868.2018.1458567

Bayeh, E. (2017). The role of empowering women and achieving gender equality to the sustainable development of Ethiopia. Pacific Science Review B: Humanities and Social Sciences, 2, 37-42. doi: 10.1016/j.psrb.2016.09.013

Cornwall, A., \& Edwards, J. (2010). Introduction: Negotiating empowerment. IDS Bulletin 41(2), 1-9. doi: 10.1111/j.1759-5436.2010.00117.x
Danjuma, S. K., Muhammad, Y. A., \& Alkali, L. F. (2013). Factors militating against women economic empowerment and poverty reduction in African countries. IOSR Journal of Business and Management, 13(6), 47-51.

Duke, J. (2010). The dynamics of women participation in democratic politics and sustainable development in Africa. Journal of Sustainable Development, 12, 83-95.

Elizabeth O. (2015). Gender inequalities and employment in Nigeria. Retrieved July 6, 2019, from https://www.researchgate.net/ publication/278026650_Gender_Inequalities_ and_Employment_in_Nigeria

Eze, J., Okechukwu, U. E., \& Gerald, N. (2016). Women empowerment: Panacea for poverty reduction and economic development in Nigeria. Journal of Policy and Development Studies, 10(2), 31-41.

Fasina, F. F. (2017). Gender discrimination and development in Nigeria: Issues and perspective. Retrieved July 6, 2019, from https://www. researchgate.net/publication/320386542_ GENDER_DISCRIMINATION_AND_ DEVELOPMENT_IN_NIGERIA_ISSUES_ AND_PERSPECTIVE/references

Fiderikumo, P., Bredino, S., \& Adesuji, A. (2017). Empowerment strategies and poverty reduction in Bayelsa State: A non-parametric approach. American Journal of Environmental and Resource Economics, 3(1), 1-5. doi: 10.11648/j. ajere.20180301.11

Fiorino, G., \& Bowels, H. (2001). Industrialization and the rural people. London, England: Macmillan.

Hora, E. A. (2014). Factors that affect women participation in leadership and decision making position. Asian Journal of Humanity, Art and Literature, 1(2), 97-118. 
Ibok, O. W., Ekanem, J. T., \& Umoh, I. U. (2015). Factors influencing the utilization of agricultural extension technologies by yam farmers in Yakurr LGA of Cross River State, Nigeria. Journal of Basic and Applied Research International, 5(2), 100-109.

Ilavbarhe, K. O., \& Izekor, O. B. (2015). The role of microcredit in women empowerment and poverty alleviation in Edo State, Nigeria. Journal of Agricultural and Crop Research, 3(6), 80-84.

International Centre for Research on Women. (2013). The issue: Women's assets and property in Ghana. Journal of the Political Economy, 11(6), 981-1022.

Josephat, P. K., Fulment, A. K., \& Matunga, B. N. (2018). Social determinants and attitudes of women on empowerment through microfinance institutions. Business and Economic Research, Macrothink Institute, 8(4), 80-99. doi: 10.5296/ ber.v8i4.13521

Karabona, R. (2015). An assessment of adult education as a strategy for women empowerment in Mkinga District (Unpublished Master's thesis), Open University of Tanzania, Tanzania.

Kazembe, L. N. (2020). Women empowerment in Namibia: Measurement, determinants and geographical disparities. World Development Perspective, 19. doi: 10.1016/j.wdp.2020.100211

Mandal, K. C. (2013). Concept and types of women empowerment. International Journal of Teaching and Studies, 9(2), 17-30.

Mbara, K. U., Anurugwo, A. O., \& Alatare, S. M. (2015). Promoting women empowerment through entrepreneurship education in Nigeria. Journal of Nigerian National Council of Adult Education, 20(1), 190-200.

Obayelu, O. A., \& Chime, A. C. (2020). Dimensions and drivers of women's empowerment in rural Nigeria. International Journal of Social Economics, 47(3), 315-333. doi: 10.1108/IJSE07-2019-0455

Oke, L. (2015). Democracy, women's political participation and the policy environment in Nigeria. Developing Country Studies, l5(10), 1-8.

Okeke, C. C. (2018). Women empowerment and development in NIGERIA. Nwafor Orizu Journal of Educational Research and Development, 4(2), 319-324.

Onah, N. (2011). Women empowerment and sustainable development in Nigeria: The role of Faith-Based Organizations. Nigerian Journal of Social Sciences, 7(2), 130-141.

Onyebuchi, N., \& Rafiu, Y. O. (2020). Managing the Nigerian rural environment through women empowerment in non-farm activities in Kajuru Local Government Area of Kaduna State. Journal of Materials Science Research and Reviews, 5(1), 31-41.

Onyishi, C. N. (2011). Empowerment and women's participation in development processes: A study of Nsukka community in Nsukka Local Government Area of Enugu State (Master's thesis), University of Nigeria Nsukka, Nigeria.

Osita, A. A. (2016). Establishment of creative industries; a panacea for rural women empowerment in Oru East Local Government Area, Imo State, Nigeria. European Journal of Education Studies, 1(4), 65-73.

Raphel, A. (2014). Women, girls and Malala: Research on gender and education in Pakistan, and beyond. Retrieved July 6, 2019, from https:// journalistsresource.org/studies/international/ human-rights/pakistan-women-equalityeducation-economic-development-researchroundup 
Sperling, G. B., Wingthrop, R., \& Kwauk, C. (2016). What works in girls' education: Evidence for the world's best investment. Washington, USA: Brookings Institution.

Syed, I. (2018). Shall I feed my daughter, or educate her?" Barriers to girls' education in Pakistan. Human Rights Watch. Retrieved August 26, 2020, from https://www.hrw.org/ report/2018/11/12/shall-i-feed-my-daughter-oreducate-her/barriers-girls-education-pakistan

Tabassum, M., Begum, N., Rana, M. S., Faruk, M. O., \& Miah, M. M. (2019). Factors influencing women's empowerment in Bangladesh. Science, Technology \& Public Policy, 3(1), 1-7. doi: 10.11648/j.stpp.20190301.11
Ugal, D. B. (2015). Socio-economic background and women empowerment in Cross River State, Nigeria: Implications for maternal health, using data from the NDHS 2008. Sociology and Anthropology, 3(11), 591-597. doi: 10.13189/ sa.2015.031103

Uwantege, K. L., \& Mbabazi, P. (2015). The impact of women economic empowerment projects on their socio-economic development in Rwanda: The case of Agaseke project. European Journal of Business and Social Sciences, 4(6), 59-87.

Uyang, F. A., Ejeje, J. A., \& Aniah, E. A. (2016). Gender inequality and women empowerment in Warri South Local Government Area of Delta State, Nigeria. European Journal of Research in Social Sciences, 4(6), 66-72. 